\title{
Orange essential oil as antimicrobial additives in poly(vinyl chloride) films
}

\author{
Carla Fabiana da Silva1, Flávia Suellen Melo de Oliveira², Viviane Fonseca Caetano², Glória Maria Vinhas²* \\ and Samara Alvachian Cardoso²
}

\author{
${ }^{1}$ Laboratório de Análises Físico-Química de Alimentos, Departamento de Ciências Domésticas, \\ Universidade Federal Rural de Pernambuco - UFPE, Recife, PE, Brasil \\ ${ }^{2}$ Laboratório de Materiais Poliméricos e Caracterização, Departamento de Engenharia Química, \\ Universidade Federal de Pernambuco - UFPE, Recife, PE, Brasil \\ *gmvinhas@yahoo.com.br
}

\begin{abstract}
In this work were developed and evaluated films of poly(vinyl chloride)-PVC additivated with orange essential oil - OEO. These films were evaluated with FT-IR spectroscopy; mechanical tests; migration OEO in simulants; and determination of stability after sterilization by gamma radiation at a dose of $25 \mathrm{kGy}$. The OEO was assessed with GC-MS and analysis of antimicrobial activity. The films were prepared by the casting solution technique. The essential oil concentrations in PVC were $2 \%, 10 \%$ and $30 \%(\mathrm{w} / \mathrm{w})$. The results showed that the OEO was incorporated into the polymer matrix and that this oil had antimicrobial activity against the bacteria E. coli and S. aureus. The migration of OEO in the films occurred with all simulants. The incorporation of OEO in the films also made them more flexible. It was also found that additive with $30 \% \mathrm{w} / \mathrm{w}$ OEO provides a protective effect for the polymer after sterilization by gamma radiation.
\end{abstract}

Keywords: antimicrobial activity, mechanical tests, migration, orange essential oil, poly(vinyl chloride).

\section{Introduction}

Food packaging has improved over the years in order to match the demands of modern society ${ }^{[1]}$. The search for alternative in packaging systems has been carried out to preserve the quality of food and prolong its commercial validity ${ }^{[2]}$. Among these systems is antimicrobial packaging, acting by the slow migration of active agents incorporated into the polymeric matrix to the surface of the food ${ }^{[3,4]}$.

One possibility for the formulation of antimicrobial packaging is to use an additive with essential oils (EOs). EOs are liquid mixtures of volatile compounds extracted from leaves, flowers, stems, roots, seeds or fruit peel that have attracted interest of the food industry for their antimicrobial nature ${ }^{[5-8]}$. This antimicrobial action is due to the presence of components that have the ability to alter the permeability of the outer membrane of micro-organisms and/or inhibit important enzymes for their growth and survival ${ }^{[9]}$.

An alternative to this kind of antimicrobial packaging would be the combination of poly(vinyl chloride) (PVC) with essential oil. PVC is one of the most consumed thermoplastics in the world, with good cost-benefit and the ability to incorporate diverse types of additives, besides being recyclable, non-toxic and inert ${ }^{[10-13]}$. PVC is a rigid polymer. This rigidity is attributed the forces of Van der Waals dipole-dipole caused by the hydrogen and chlorine attached to the same carbon atom ${ }^{[12]}$. The additives incorporated in the PVC can change their characteristics, such as the decrease in the rigidity or transparency; to promote greater resistance to weathering conditions; to promote antimicrobial action; and combined changes ${ }^{[13-15]}$.

A potential antimicrobial agent is the orange essential oil (OEO). This oil has d-limonene as its main antimicrobial agent. This is a monocyclic monoterpene extracted from citrus peel, easily absorbed into the polymer matrix; and has intense antimicrobial activity, making it attractive for the food packaging industry ${ }^{[14]}$. Furthermore, the extraction of essential oil orange can be considered a sustainable raw material, as the shell of the citrus fruit is considered a loss to the industry of fruit juice ${ }^{[16,17]}$. In the literature reporting PVC added with substances that have the function of stabilizers, plasticizers or viscosity increasing agent, such inseed oil and gum rosin ${ }^{[18]}$. Also, works are reported of limonene added to other polymers, such as PLA ${ }^{[14,19,20]}$, blends of PHB/PLA ${ }^{[21,22]}$, starch-sodium caseinate blend films ${ }^{[23]}$ and chitosan films ${ }^{[14,24,25]}$. In literature also are reported workes that used other essential oils with polymers, such as gelatin films with citrus oils ${ }^{[26]}$, chitosan films with cinnamon oil ${ }^{[27]}$; films from soy protein with cinnamon oil ${ }^{[28]}$, k-carrageenan film with savory oil ${ }^{[29]}$, chitosan films with basil ${ }^{[30]}$, films from whey protein with oregano oil ${ }^{[31]}$ and chitosan films with Zataria oil multiflora ${ }^{[32]}$.

This study were developed and evaluated PVC films additivated with orange essential oil aiming towards the application to antimicrobial packaging for the food industry. The additive with this EO permits a greater interaction of the packaging with the food an important differential compared to conventional packaging. 


\section{Materials and Methods}

\subsection{Materials}

The orange essential oil (OEO) with specific density of $0.8420 \mathrm{~g} / \mathrm{mL}$ was donated by AGROTERRENAS Company (São Paulo - BR) and the polymer was donated by TELETRON (Pernambuco - BR). The solvent tetrahydrofuran (THF) used from Sigma Aldrich. Text paragraph within a first subsection.

\subsection{Characterization of the OEO by GC-MS}

Characterization of the essential oil was performed with a gas chromatography mass spectrometry (GC-MS) system from Thermo Scientific. The chromatograph was a Trace 1300 model. The mass spectrometer was the ISQ Single Quadrupole system. The temperature parameters were used were: $\mathrm{GC}$ oven ramp $60^{\circ} \mathrm{C}$ for $3 \min \left(10^{\circ} \mathrm{C} / \min\right.$ to $\left.300^{\circ} \mathrm{C}\right)$ and $300{ }^{\circ} \mathrm{C}$ for $15 \mathrm{~min}$; injector temperature $270{ }^{\circ} \mathrm{C}$; MS temperature of the transfer line $280^{\circ} \mathrm{C}$; and MS source temperature of $250^{\circ} \mathrm{C}$ ions.

\subsection{Production of polymer films}

The films were produced by the solution casting method with $1.5 \mathrm{~g}$ of PVC and $50 \mathrm{~mL}$ of THF ${ }^{[33]}$. The PVC films were prepared by additivating with orange essential oil in different amounts $(0,2,10$ and $30 \% \mathrm{w} / \mathrm{w})$. The orange essential oil was added to the polymer according to the methodology adopted by Morelli et al. ${ }^{[34]}$. The glass Petri dishes used in the solvent evaporation step had the following dimensions: $15.0 \times 2.0 \mathrm{~cm}$. The PVC films and PVC additivated with OEL had an average thickness of $(0.083+0.015) \mathrm{mm}$.

\subsection{Mechanical properties}

Mechanical tests were carried out in a universal tensile testing instrument, DL-500MF brand model EMIC, in accordance with the ASTM D882-12 standard ${ }^{[35]}$. Assays were conducted at room temperature without humidity control. Assays were performed under the following conditions: load cell of $500 \mathrm{~N}$; jaw speed of $100 \mathrm{~mm} / \mathrm{min}$; initial distance between the jaws $40 \mathrm{~mm}$; and dimension of the specimen $(20 \times 50) \mathrm{mm}$. For each film composition, there were 9 replicates.

\subsection{Mid-infrared spectra acquisition (FTIR)}

Mid-infrared (MIR) spectra of the films were acquired in a Tensor 27 spectrometer (Bruker) with an Attenuated Total Reflectance-ATR accessory. The spectra of the films were recorded under the following conditions: mid-infrared region $4000-400 \mathrm{~cm}^{-1}$, resolution of $4 \mathrm{~cm}^{-1}$ and 16 scans.

\subsection{Migration test}

To follow the migration of orange essential oil, we used mid-infrared spectroscopy, using the attenuated total reflection technique (ATR) ${ }^{[4]}$. The conditions chosen were: spectral range 1670 to $1616 \mathrm{~cm}^{-1}$; resolution of $4 \mathrm{~cm}^{-1}$; and 16 scans. Samples of scale films (30x10) mm were used in the migration tests. To perform the test, the samples were immersed in food simulants: distilled water, olive oil and $10 \%$ ethanol. Each film sample was immersed in $6 \mathrm{~mL}$ of simulant, sealed and placed in a hot air oven at $40{ }^{\circ} \mathrm{C}$. The migration periods were monitored at $0,36,84$ and 162 hours.

\subsection{Antimicrobial activity of OEL}

The activity of the orange essential oil was investigated by disk diffusion assay with medium Plate Count Agar (PCA ${ }^{[36]}$. Filter paper disks of $2 \mathrm{~cm}$ diameter were utilized, having been sterilized by UV irradiation for $10 \mathrm{~min}$ (each side for $5 \mathrm{~min}$ ). Aliquots of $0.5 \mathrm{~mL}$ of $S$. aureus (ATCC 6538) and E. coli (ATCC 8739 ) in the order of $10^{7} \mathrm{CFU} / \mathrm{mL}$, were quantified by turbidity on the Mcfarland comparison scale. They were inoculated into the PCA by the pour plate method. After solidification of the PCA, these were placed on discs immersed with orange essential oil, in the center of the petri dish. The plates were incubated at $35^{\circ} \mathrm{C}$ for $48 \mathrm{~h}$.

\subsection{Radiolytic sterilization of films}

The films were exposed to gamma radiation with a Gammacell (GC)-220 Cobalt-60 irradiator at a dose of $25 \mathrm{kGy}$. This dose is also used to sterilize the food packaging ${ }^{[37]}$.

\subsection{Statistical analysis}

All data were analyzed by One-way analysis of variance (ANOVA) using Duncan's test for comparison between the means $(\mathrm{p}<0.05)$. The statistical analyses were performed with STATISTICA 7.0 software.

\section{Results and Discussion}

\subsection{GC-MS of orange essential oil}

The GC-MS analysis identified over 150 constituents present in the OEO. Figure 1 highlights main constituents, representing $89.78 \%$ of the oil composition.

Figure 1 shows the major components of the $\mathrm{OEO}$ were p-Mentha-1(7),3-dieno (1), D-Limoneno (2), Linalol (3), Decanal (4), n-Hexadecanoic acid (5) and cis-13-Octadecenoic acid (6). These compounds are classified as terpenes, alcohol, aldehyde and carboxylic acids and their molecular structures are summarized in Table 1, with their respective retention times (RT) and peak areas.

The most known for their antimicrobial compounds are the phenols, terpenes and aldehydes. These act by altering the concentration of fatty acids in the microbial cell membrane, causing damage to its structure ${ }^{[38]}$.

D-limonene was expected as the major constituent as described in the literature on Citrus oils ${ }^{[39]}$. Other authors who studied Citrus oils quantified $84.7 \%$ in grapefruit oil, $94.51 \%$ in orange oil and $60.0 \%$ in lemon oil ${ }^{[40-42]}$.

\subsection{Mid-infrared spectra (FTIR) of PVC/OEO films}

Figure 2 shows the FTIR spectra obtained in the mid-infrared region of orange essential oil, pure PVC film and PVC films additivated with 2, 10 and $30 \% \mathrm{w} / \mathrm{w}$ of orange essential oil. In this figure the main bands have been identified in accordance with the literature, found in pure PVC film which are 2911, 1249, 957, 837 and $616 \mathrm{~cm}^{-1}$ related to the $\mathrm{CH}$ stretching, $\mathrm{CH}$ rocking, trans $\mathrm{CH}$ wagging $\mathrm{C}-\mathrm{Cl}$ stretching and cis $\mathrm{CH}$ wagging, respectively ${ }^{[43]}$. In PVC 


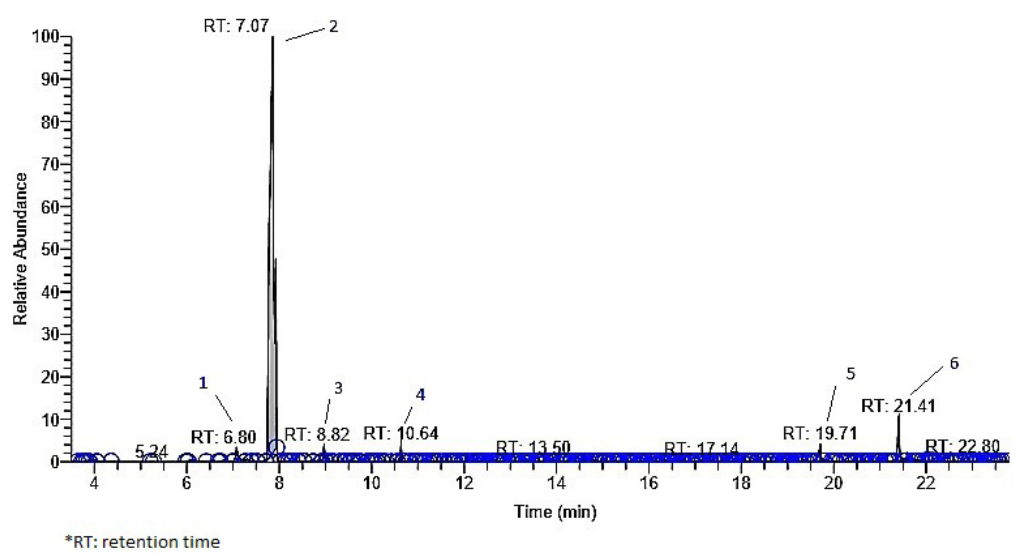

Figure 1. GC-MS chromatogram of orange essential oil (OEO).

Table 1. Major components orange essential oil determined by GC-MS.

\begin{tabular}{cccc}
\hline Number & Component & Retention time (RT) (min) & Peak area (\%) \\
\hline 1 & p-Mentha-1(7), 3-diene & 6.80 & 1.98 \\
2 & Limonene & 7.07 & 79.97 \\
3 & Linalol & 8.82 & 1.11 \\
4 & Decanal & 10.64 & 0.93 \\
5 & n-Hexadecanoic acid & 19.71 & 1.84 \\
6 & cis-13-Octadecenoic acid & 21.41 & 3.95 \\
\hline
\end{tabular}

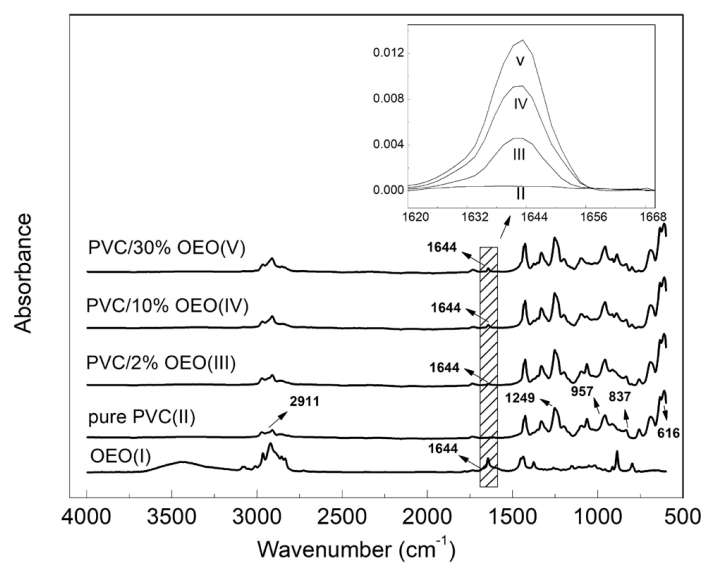

Figure 2. FTIR spectra of the orange essential oil (OEO), pure poly(vinyl chloride) film (PVC) and poly(vinyl chloride) films additivated with 2,10 and $30 \%$ of $w / w$ of orange essential oil (PVC/2\%OEO, PVC/10\%OEO and PVC/30\%OEO, respectively).

films additivated with orange essential oil, a $1644 \mathrm{~cm}^{-1}$ peak band is observed. This band gives evidence of the presence of orange essential oil which is identified as the stretch of the $\mathrm{C}=\mathrm{C}$ bond. This band is present in orange essential oil, but it is not present in the PVC FTIR spectrum, so this band can be used for purposes of evaluating oil migration in a food simulant environment. In Figure 3 there is a $1670-1616 \mathrm{~cm}^{-1}$ region in the spectra of films evaluated. As can be seen in Figure 3, the increased peak of the band is due to the increase in the percentage of oil.

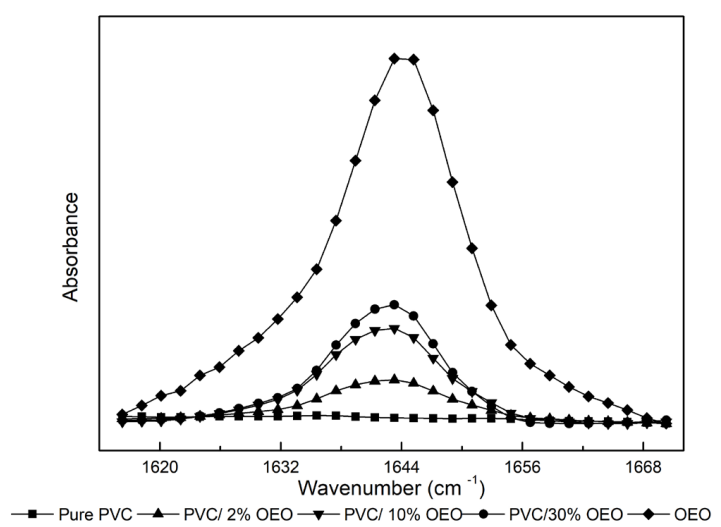

Figure 3. FTIR spectra of the orange essential oil (OEO), pure poly(vinyl chloride) film (PVC) and poly(vinyl chloride) films additivated with 2,10 and $30 \%$ of $w / w$ of orange essential oil (PVC/2\%OEO, PVC/10\%OEO and $\mathrm{PVC} / 30 \% \mathrm{OEO}$, respectively) in the region of $1616-1670 \mathrm{~cm}^{-1}$.

\subsection{Migration test of the orange essential oil}

For migration analysis, samples of PVC films were evaluated. These PVC films were additivated with $2 \%, 10 \%$ and $30 \% \mathrm{w} / \mathrm{w}$ of OEO exposed to the following chemical agents: $10 \%$ ethanol, olive oil and water. These media simulate alcoholic foods (ethanol), greasy food (olive oil) and aqueous non-acid foods ( $\mathrm{pH}>4.5$ ) (water), as established by Resolution $\mathrm{N}^{\circ} .32$ of the Common Market Group, MERCOSUR (2010) ${ }^{[4]}$. The acquisition of the spectra was carried out in periods of $0,36,84$ and 162 hours. Figure 4 
shows the spectra of PVC samples additivated with $2 \% \mathrm{w} / \mathrm{w}$ of OEO. The essential oil migration to the film surface can be observed by the decrease in peak at the $1644 \mathrm{~cm}^{-1}$ band.

Figure 4 shows a decrease in the intensity of the peak at periods of 36, 84 and 162 hours. This migration is justified by the diffusion mechanism that is strongly influenced by interactions occurring between the media and the packaging material $^{[45]}$.

Figure 5 illustrates the spectra of PVC samples with $30 \% \mathrm{w} / \mathrm{w}$ of OEO. Figure $5 \mathrm{a}$ shows that OEO migration in the ethanol simulant occurs gradually over the period. Figure $5 \mathrm{~b}$ shows migration in the simulant olive oil with higher speed, being completed in the first $36 \mathrm{~h}$. Figure $5 \mathrm{c}$ shows OEO migration at a slower speed, as can be verified by the intensity of the peak at $1644 \mathrm{~cm}^{-1}$.

The migration of orange essential oil in the simulant olive oil occurred with higher speed due to the affinity and solubility between them. The diffusion of the active agent

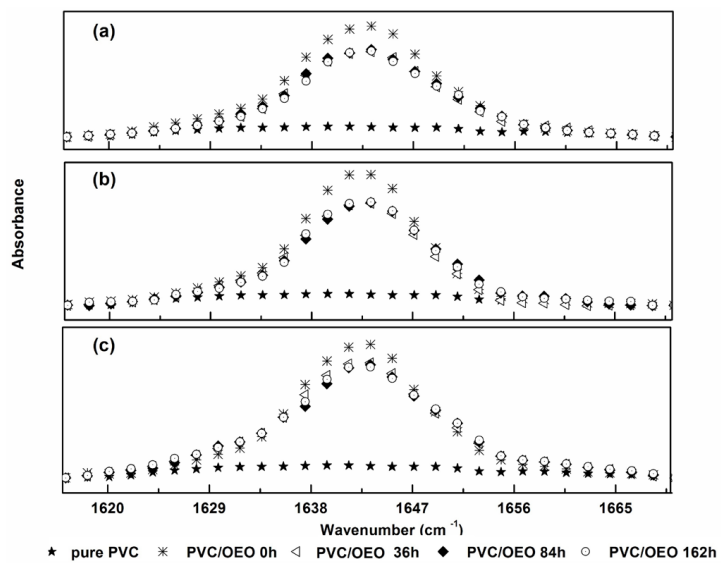

Figure 4. Migration in pure poly(vinyl chloride) film (PVC) and poly(vinyl chloride) film additivated with $2 \%$ of w/w of orange essential oil (PVC/OEO) in the simulants: (a) ethanol; (b) olive; and (c) water by Infrared.
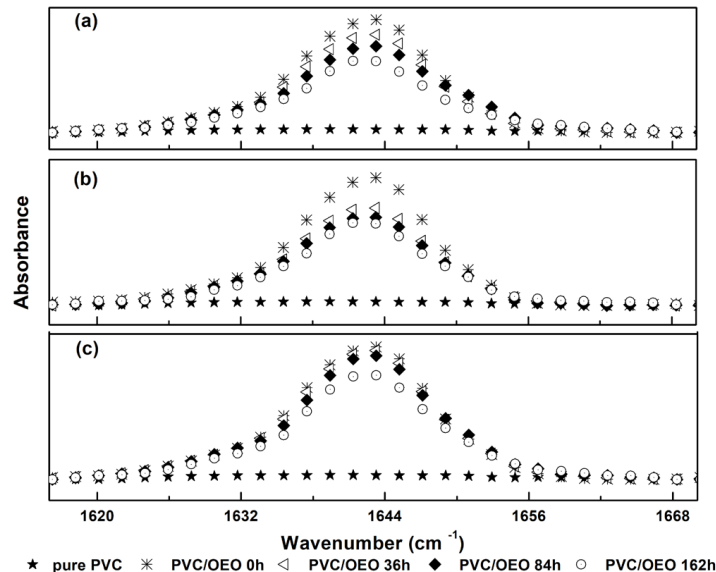

Figure 5. Migration in pure poly(vinyl chloride) film (PVC) and poly(vinyl chloride) film additivated with $30 \%$ of $w / w$ of orange essential oil (PVC/OEO) in the simulants: (a) ethanol; (b) olive; and (c) water by Infrared. and its solubility of the polymer is extremely important to define the basic conditions for their use. The diffusion behavior of chemicals incorporated in the polymers is a very complex process and depends on several parameters, such as the concentration of substances in the packing, nature of the food, temperature and the period of time during which the contact lasts ${ }^{[46]}$. In the literature, there are studies that have evaluated the migration of limonene in other polymers. Authors evaluated the diffusion of limonene in low-density polyethylene film ${ }^{[47]}$.They found that limonene diffusion velocity in the polymer was low due to the morphological differences in the polymer.

\subsection{Antimicrobial activity of OEL}

Figures $6 \mathrm{a}$ and $6 \mathrm{~b}$ illustrate the antimicrobial test through the zone of inhibition for $S$. aureus (Gram positive) and E. coli (Gram-negative). It can be seen that these figures the zone of inhibition showed antimicrobial activity for the bacteria tested in the oil. Diameters of the inhibition halos shown in Figures $6 \mathrm{a}$ and $6 \mathrm{~b}$ were 21,6 $\mathrm{mm}$ and $38,5 \mathrm{~mm}$, respectively. The antimicrobial activity of orange essential oil has also been observed by other authors ${ }^{[48,49]}$.

\subsection{Mechanical properties}

Table 2 shows the results of tensile tests for mechanical properties, using Young's modulus, percentage elongation at break and tensile strength of PVC films, $\mathrm{PVC} / 2 \% \mathrm{OEO}$, $\mathrm{PVC} / 10 \% \mathrm{OEO}$ and $\mathrm{PVC} / 30 \% \mathrm{OEO}$. The mean values of the mechanical properties obtained through the mechanical tests were compared statistically with Duncan's test at a significance level of $5 \%(p<0.05)$. We verified that there was a reduction of the values of Young's modulus for the additive with $30 \% \mathrm{w} / \mathrm{w}$ of OEO. For the percentage elongation at break, the values presented no statistical differences for the level of significance of 5\%. For maximum stress, significant changes were observed from the additive with $10 \% \mathrm{w} / \mathrm{w}$ of OEO.

Table 3 shows the results of tensile tests for Young's modulus, percentage elongation at break and tensile strength of PVC films, $\mathrm{PVC} / 2 \% \mathrm{OEO}, \mathrm{PVC} / 10 \% \mathrm{OEO}$ and $\mathrm{PVC} / 30 \%$ $\mathrm{OEO}$ after exposure to gamma radiation. The mean values of the mechanical properties were compared statistically by Duncan's test at a significance level of $5 \%(p<0.05)$. This verified that there were no significant changes in the values of Young's modulus. For the percentage elongation at break, there was a decrease in value of this property with the additive at $30 \% \mathrm{w} / \mathrm{w}$ of OEO.

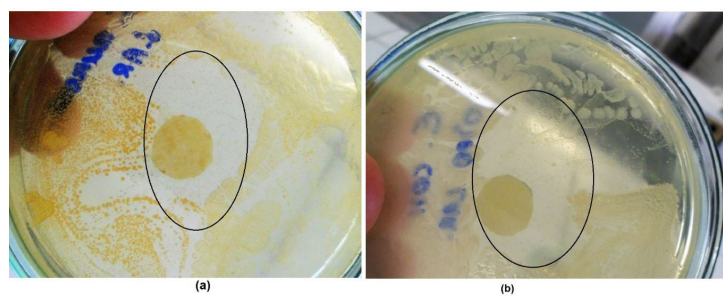

Figure 6. Antimicrobial test through the zone of inhibition: (a) S. aureus (Gram positive); (b) E. coli (Gram-negative). 
Table 2. Average values obtained for the mechanical properties tensile strength, percentage elongation at break and Young's modulus in pure poly(vinyl chloride) film (PVC) and poly(vinyl chloride) films additivated with 2, 10 and 30\% of w/w of orange essential oil (PVC/2\%OEO, PVC/10\%OEO and $\mathrm{PVC} / 30 \% \mathrm{OEO}$, respectively).

\begin{tabular}{cccc}
\hline Samples & Young's Modulus (MPa)* & Elongation-at-break (\%)* & Maximum Tensile(MPa)* \\
\hline PVC/2\%OEO & $1224.00 \pm 28.83^{\mathrm{a}}$ & $5.628 \pm 0.197^{\mathrm{a}}$ & $42.150 \pm 1.451^{\mathrm{a}}$ \\
PVC/10\%OEO & $1153.00 \pm 143.28^{\mathrm{a}}$ & $6.056 \pm 0.030^{\mathrm{a}}$ & $31.505 \pm 1.278^{\mathrm{b}}$ \\
PVC/30\%OEO & $755.93 \pm 37.46^{\mathrm{b}}$ & $6.018 \pm 0.726^{\mathrm{a}}$ & $33.410 \pm 2.272^{\mathrm{b}}$ \\
PVC & $1275.00 \pm 77.79^{\mathrm{a}}$ & $5.901 \pm 0.344^{\mathrm{a}}$ & $43.580 \pm 0.850^{\mathrm{a}}$ \\
\hline
\end{tabular}

*Values are presented as means \pm standard deviation. Different letters in the same column indicate significant differences $(\mathrm{p}<0.05)$.

Table 3. Average values obtained for the mechanical properties tensile strength, percentage elongation at break and Young's modulus of the irradiated samples in pure poly(vinyl chloride) film (PVC) and poly(vinyl chloride) films additivated with 2, 10 and $30 \%$ of w/w of orange essential oil (PVC/2\%OEO, PVC/10\%OEO and $\mathrm{PVC} / 30 \% \mathrm{OEO}$, respectively).

\begin{tabular}{cccc}
\hline Samples & Young's Modulus (MPa)* & Elongation-at-break (\%)* $^{*}$ & Maximum Tensile (MPa)* $^{*}$ \\
\hline PVC/2\%OEO & $0.083 \pm 0.006^{\mathrm{a}}$ & $1059.77 \pm 112.18^{\mathrm{a}}$ & $6.232 \pm 0.090^{\mathrm{a}}$ \\
$\mathrm{PVC} / 10 \% \mathrm{OEO}$ & $0.076 \pm 0.025^{\mathrm{a}}$ & $941.65 \pm 89.76^{\mathrm{a}}$ & $6.062 \pm 0.192^{\mathrm{a}}$ \\
$\mathrm{PVC} / 30 \% \mathrm{OEO}$ & $0.089 \pm 0.029^{\mathrm{a}}$ & $738.17 \pm 10.01^{\mathrm{b}}$ & $5.770 \pm 0.575^{\mathrm{ab}}$ \\
PVC & $0.076 \pm 0.011^{\mathrm{a}}$ & $947.72 \pm 44.19^{\mathrm{a}}$ & $5.476 \pm 0.169^{\mathrm{b}}$ \\
\hline
\end{tabular}

*Values are presented as means \pm standard deviation. Different letters in the same column indicate significant differences $(\mathrm{p}<0.05)$.

Comparing the mean values for each property before and after gamma radiation, we observed that there was a reduction in all parameters for each PVC film with oil additives. Similar result was observed in the work done by Landgraf ${ }^{[37]}$. The author affirms that although sterilization by gamma radiation at $25 \mathrm{kGy}$ dose inactivates the antimicrobial agent, the highly reactive species generated in the irradiation process can have undesirable effects on packaging materials, degrading the polymer may lower its resistance, change the color and transparency.

A comparison of the reduction obtained before and after the sterilization process showed that the Young's modulus of the control film decreased by $25.67 \%$, while for the films with $30 \%$ OEO this reduction was only $2.35 \%$. For elongation, these reductions were $7.20 \%$ and $4.12 \%$, respectively for the film control and 30\% OEO. For maximum stress, there was a reduction of $1.23 \%$ for the films with $30 \%$ OEO and an increase of $11.17 \%$ for the control film. These results indicate that irradiation affects in the PVC film is more intense in the PVC film without OEO, while in the presence of $30 \% \mathrm{w} / \mathrm{w}$ of OEO these changes were minimal.Accordingto Uzeli (2013), packaging properties should be maintained after sterilization ${ }^{[50]}$. Thus, PVC films with $30 \%$ orange oil meets this requirement.

Table 3 also shows that the flexibility in PVC film with oil increased after sterilization by gamma radiation. This is important for packaging, since flexibility is a desirable property for this polymer.

\section{Conclusions}

OEO presented antimicrobial activity to E. coli and S. aureus, two microorganism pathogens of great relevance to food area. Through the results of the migration test, it was found that the OEO migration speed for each food simulant is related to the amount of additive used in the active film. The higher the percentage of additives, the most essential oil migration speed to the surface of the film. The mechanical properties demonstrated that in the presence of OEO, the PVC films were more flexible, even after being irradiated with gamma radiation. The results from the mechanical and migration properties showed that orange essential oil is promising for use in antimicrobial packages, because the essential oil is an antimicrobial agent that migrates to the surface of the film in food simulants and also contributes to improve flexibility of the film.

\section{Acknowledgements}

The authors thank the Fundação de Amparo Ciência e Tecnologia do Estado de Pernambuco (FACEPE) for the provided scholarship. The materials donated by companies AGROTERRENAS Company and TELETRON. The English text of this paper was revised by Sidney Pratt, Canadian, MAT (The Johns Hopkins University), RSAdip - TESL (Cambridge University).

\section{References}

1. Realini, C. E., \& Marcos, B. (2014). Active and intelligent packaging systems for a modern society. Meat Science, 98(3), 404-419. http://dx.doi.org/10.1016/j.meatsci.2014.06.031. PMid:25034453.

2. Sung, S.-Y., Sin, L. T., Tee, T. T., Bee, S.-T., Rahmat, A. R., Rahman, W. A. W. A., Tan, A.-C., \& Vikhraman, M. (2013). Antimicrobial agents for food packaging applications. Trends in Food Science \& Technology, 33(2), 110-123. http://dx.doi. org/10.1016/j.tifs.2013.08.001.

3. Barbosa-Pereira, L., Aurrekoetxea, G. P., Ângulo, I., PaseiroLosada, P., \& Cruz, J. M. (2014). Development of new active packaging films coated with natural phenolic compounds to improve the oxidative stability of beef. Meat Science, 97(2), 249-254. http://dx.doi.org/10.1016/j.meatsci.2014.02.006. PMid:24598072.

4. Pires, M., Petzhold, C. L., Santos, R. V., Perão, L., \& Chies, A. P. (2014). Effect of antimicrobial compound migration on final properties of polyethylene based film. Polimeros: Ciência e Tecnologia, 24(2), 237-242. http://dx.doi.org/10.4322/ polimeros.2014.031. 
5. Amorati, R., Foti, M. C., \& Valgimigli, L. (2013). Antioxidant activity of essential oils. Journal of Agricultural and Food Chemistry, 61(46), 10835-10847. http://dx.doi.org/10.1021/ jf403496k. PMid:24156356.

6. Siddique, A. B., Rahman, S. M. M., \& Hossain, M. A. (2012). Chemical composition of essential oil by different extraction methods and fatty acid analysis of the leaves of Stevia Rebaudiana Bertoni. Arabian Journal of Chemistry, 9(2), 1185-1189. http:// dx.doi.org/10.1016/j.arabjc.2012.01.004.

7. Debiagi, F., Kobayashi, R. K. T., Nakazato, G., Panagio, L. A., \& Mali, S. (2014). Biodegradable active packaging based on cassava bagasse, polyvinylalcohol and essential oils. Industrial Crops and Products, 52, 664-670. http://dx.doi.org/10.1016/j. indcrop.2013.11.032.

8. Siroli, L., Patrignani, F., Gardini, F., \& Lanciotti, R. (2015). Effects of sub-lethal concentrations of thyme and oregano essential oils, carvacrol, thymol, citral and trans-2-hexenal on membrane fatty acid composition and volatile molecule profile of Listeria monocytogenes, Escherichia coli and Salmonella enteritidis. Food Chemistry, 182(1), 185-192. http://dx.doi. org/10.1016/j.foodchem.2015.02.136. PMid:25842326.

9. Cunha, P. A., Roque, O. R., \& Nogueira, M. T. (2012). Plantas aromáticas e óleos essenciais, composição e aplicações. Lisboa: Fundação Calouste Gulbenkian.

10. Silva, T. H., Oliveira, J. E., \& De Medeiros, E. S. (2015). Obtenção de micro e nanofibras de PVC pela técnica de Fiação por Sopro em Solução. Polímeros: Ciência e Tecnologia, 25(2), 229-235. http://dx.doi.org/10.1590/0104-1428.1694.

11. Madaleno, E., Rosa, D. S., Zawadzki, S. F., Pedrozo, T. H., $\&$ Ramos, L. P. (2009). Study of the use of plasticizer from renewable sources in PVC compositions. Polimeros: Ciência e Tecnologia, 19(4), 263-270. http://dx.doi.org/10.1590/S010414282009000400004 .

12. Nunes, L. R., Rodolfo, A., Jr., \& Ormanji, W. (2006). Tecnologia do PVC. São Paulo: ProEditores/Braskem.

13. Instituto do PVC. (2015). São Paulo. Retrieved in 2015, June 22, from http://migre.me/vNI3x

14. Arrieta, M. P., López, J., Ferrándiz, S., \& Peltzer, M. A. (2013). Characterization of PLA-limonene blends for food packaging applications. Polymer Testing, 32(4), 760-768. http://dx.doi. org/10.1016/j.polymertesting.2013.03.016.

15. Rabello, M., \& Paoli, M. A. (2013). Aditivação de termoplásticos. São Paulo: Artliber.

16. Mendonça, L. M. V. L., Conceição, A., Piedade, J., Carvalho, V. D., \& Theodoro, V. C. A. (2006). Caracterização da composição química e do rendimento dos resíduos industriais do limão Tahiti (Citrus latifolia Tanaka). Food Science and Technology, 26(4), 870-874. http://dx.doi.org/10.1590/S010120612006000400025.

17. Settanni, L., Palazzolo, E., Guarrasi, V., Aleo, A., Mammina, C., Moschetti, G., \& Germanà, M. A. (2012). Inhibition of foodborne pathogen bacteria by essential oils extracted from citrus fruits cultivated in Sicily. Food Control, 26(2), 326-330. http://dx.doi.org/10.1016/j.foodcont.2012.01.050.

18. Arrieta, M. P., Samper, M. D., Jiménez-López, M., Aldas, M., \& López, J. (2017). Combined effect of linseed oil and gum rosin as natural additives for PVC. Industrial Crops and Products, 99, 196-204. http://dx.doi.org/10.1016/j.indcrop.2017.02.009.

19. Fortunati, E., Luzi, F., Puglia, D., Dominici, F., Santulli, C., Kenny, J. M., \& Torre, L. (2014). Investigation of thermomechanical, chemical and degradative properties of PLAlimonene films reinforced with cellulose nanocrystals extracted from Phormium tenax leaves. European Polymer Journal, 56, 77-91. http://dx.doi.org/10.1016/j.eurpolymj.2014.03.030.

20. Arrieta, M. P., López, J., Ferrándiz, S., \& Peltzer, M. A. (2015). Effect of d-limonene on the stabilization of poly (lactic acid).
Acta Horticulturae, (1065), 719-725. http://dx.doi.org/10.17660/ ActaHortic.2015.1065.90.

21. Arrieta, M. P., López, J., Hernández, A., \& Rayón, E. (2014). The potential of $d(+)$-limonene to improve pla-phb blends properties. In K. Hayat (Ed.), Citrus: molecular phylogeny, antioxidant properties and medicinal uses (pp. 185-197). United States: Nova Science Publishers.

22. Arrieta, M. P., López, J., Hernández, A., \& Rayón, E. (2014). Ternary PLA-PHB-Limonene blends intended for biodegradable food packaging applications. European Polymer Journal, 50, 255-270. http://dx.doi.org/10.1016/j.eurpolymj.2013.11.009.

23. Jiménez, A., Sánchez-González, L., Desobry, S., Chiralt, A., \& Tehrany, E. A. (2014). Influence of nanoliposomes incorporation on properties of film forming dispersions and films based on corn starch and sodium caseinate. Food Hydrocolloids, 35 , 159-169. http://dx.doi.org/10.1016/j.foodhyd.2013.05.006.

24. Sánchez-González, L., Chafer, M., González-Martínez, C., Chiralt, A., \& Desobry, S. (2011). Study of the release of limonene present in chitosan films enriched with bergamot oil in food simulants. Journal of Food Engineering, 105(1), 138-143. http://dx.doi.org/10.1016/j.jfoodeng.2011.02.016.

25. Randazzo, W., Jiménez-Belenguer, A., Settanni, L., Perdones, A., Moschetti, M., Palazzolo, E., Guarrasi, V., Vargas, M., Germanà, M. A., \& Moschetti, G. (2016). Antilisterial effect of citrus essential oils and their performance in edible film formulations. Food Control, 59, 750-758. http://dx.doi. org/10.1016/j.foodcont.2015.06.057.

26. Tongnuanchan, P., Benjakul, S., \& Prodpran, T. (2012). Properties and antioxidant activity of fish skin gelatin film incorporated with citrus essential oils. Food Chemistry, 134(3), 1571-1579. http://dx.doi.org/10.1016/j.foodchem.2012.03.094. PMid:25005982.

27. Atares, L., De Jesús, C., Talens, P., \& Chiralt, A. (2010). Characterization of SPI- based edible films incorporated with cinnamon or ginger essential oils. Journal of Food Engineering, 99(3), 384-391. http://dx.doi.org/10.1016/j. jfoodeng.2010.03.004.

28. Ojagh, S. M., Rezaei, M., Razavi, S. H., \& Hosseini, S. M. H. (2010). Development and evaluation of a novel biodegradable film made from chitosan and cinnamon essential oil with low affinity toward water. Food Chemistry, 122(1), 161-166. http:// dx.doi.org/10.1016/j.foodchem.2010.02.033.

29. Shojaee-Aliabadi, S., Hosseini, H., Mohammadifar, M. A., Mohammadi, A., Ghasemlou, M., Ojagh, S. M., Hosseini, S. M., \& Khaksar, R. (2013). Characterization of antioxidant antimicrobial k-carrageenan films containing Satureja hortensis essential oil. International Journal of Biological Macromolecules, 52(1), 116-124. http://dx.doi.org/10.1016/j. ijbiomac.2012.08.026. PMid:22959956.

30. Bonilla, J., Atares, L., Vargas, M., \& Chiralt, A. (2012). Edible films and coatings to prevent the detrimental effect of oxygen on food quality: possibilities and limitations. Journal of Food Engineering, 110(2), 208-213. http://dx.doi.org/10.1016/j. jfoodeng.2011.05.034.

31. Zinoviadou, K. G., Koutsoumanis, K. P., \& Biliaderis, C. G. (2010). Physical and thermo-mechanical properties of whey protein isolate films containing antimicrobials, and their effect against spoilage flora of fresh beef. Food Hydrocolloids, 24(1), 49-59. http://dx.doi.org/10.1016/j.foodhyd.2009.08.003.

32. Moradi, M., Tajik, H., Rohani, S. M. R., Oromiehie, A. R., Malekinejad, H., Aliakbarlu, J., \& Hadian, M. (2012). Characterization of antioxidant chitosan film incorporated with Zataria multiflora Boiss essential oil and grape seed extract. Food Science and Technology, 46(2), 477-484. http://dx.doi. org/10.1016/j.lwt.2011.11.020. 
33. Rocha, G. O., Farias, M. G., Carvalho, C. W. P., Ascheri, J. L. R., \& Galdeano, M. C. (2014). Filmes compostos biodegradáveis a base de amido de mandioca e proteína de soja. Polímeros: Ciência e Tecnologia, 24(5), 587-595. http:// dx.doi.org/10.1590/0104-1428.1355.

34. Morelli, C. L., Mahrous, M., Belgacem, M. N., Branciforti, M. C., Bretas, R. E. S., \& Bras, J. (2015). Natural copaiba oil as antibacterial agent for bio-based active packaging. Industrial Crops and Products, 70, 134-141. http://dx.doi.org/10.1016/j. indcrop.2015.03.036.

35. American Society for Testing and Materials-ASTM. (2012). ASTM D882-12: standard test method for tensile properties of thin plastic sheeting. Philadelphia: ASTM.

36. Nagy, E., Justesen, U. S., Eitel, Z., \& Urbán, E. (2015). Development of EUCAST disk diffusion method for susceptibility testing of the Bacteroides fragilis group isolates. Anaerobe, 31, 65-71. http://dx.doi.org/10.1016/j.anaerobe.2014.10.008. PMid:25464140.

37. Landgraf, M. (2008). Controle de desenvolvimento microbiano nos alimentos. In B. D. G. M. Franco \& M. Landgraf (Eds.), Microbiologia dos alimentos (pp. 109-148). São Paulo: Atheneu.

38. Donsi, F., Wang, Y., \& Huang, Q. (2011). Freeze-thaw stability of lecithin and modified starch-based nanoemulsions. Food Hydrocolloids, 25(5), 1327-1336. http://dx.doi.org/10.1016/j. foodhyd.2010.12.008.

39. Muller, P. S. (2011). Microencapsulação do óleo essencial de laranja (Dissertação de mestrado). Programa de Pós-graduação em Tecnologia de Alimentos, Universidade Federal do Paraná, Curitiba.

40. Teixeira, B., Marques, A., Ramos, C., Neng, N. R., Nogueira, J. M. F., Saraiva, J. A., \& Nunes, M. L. (2013). Chemical composition and antibacterial and antioxidant properties of commercial essential oils. Industrial Crops and Products, 43, 587-595. http://dx.doi.org/10.1016/j.indcrop.2012.07.069.

41. Ascheri, D. P. R., Marquez, M. O. M., \& Martucci, E. T.. (2003). Microencapsulação de óleo essencial de laranja: seleção de material de parede. Ciência e Tecnologia dos Alimentos, 23, 1-6. http://dx.doi.org/10.1590/S0101-20612003000400002.

42. Santos, J. C., Carvalho, C. D. C., Fo., Barros, T. F., \& Guimarães, A. G. (2011). In vitro antimicrobial activity of essential oils from oregano, garlic, clove and lemon against pathogenic bacteria isolated from Anomalocardia brasiliana.
Semina: Ciências Agrárias, 32(4), 1557-1564. http://dx.doi. org/10.5433/1679-0359.2011v32n4p1557.

43. Ramesh, S., \& Yi, L. J. (2009). FTIR spectra of plasticized high molecular weight PVC-LiCF3SO3 electrolytes. Ionics, 15(4), 413-420. http://dx.doi.org/10.1007/s11581-008-0279-z.

44. Common Market Group - CMG. (2010). Mercosur/CMG/ Res. n. 32/10: Mercosur technical regulation on migration from plastic materials, packages and equipments intended to come in contact with foods tuffs. Buenos Aires: CMG.

45. Padula, M., \& Cuervo, M. (2004). Legislação de embalagem para contato com alimentos: MERCOSUL e outros países Latinoamericados. Polímeros: Ciência e Tecnologia, 14(1), 8-13. http://dx.doi.org/10.1590/S0104-14282004000100004.

46. Bhunia, K., Sablani, S. S., Tang, J., \& Rasco, B. (2013). Migration of chemical compounds from packaging polymers during microwave, conventional heat treatment, and storage. Comprehensive Reviews in Food Science and Food Safety, 12(5), 523-545. http://dx.doi.org/10.1111/1541-4337.12028.

47. Cava, D., Catala, R., Gavara, R., \& Lagaron, J. M. (2005). Testing limonene diffusion through food contact polyethylene by FT-IR spectroscopy: film thickness, permeant concentration and outer medium effects. Polymer Testing, 24(4), 483-489. http://dx.doi.org/10.1016/j.polymertesting.2004.12.003.

48. Gerhardt, C., Wiest, J. M., Girolometto, G., Silva, M. A. S., \& Weschenfelder, S. (2012). Utilization of citrus by-products in food perspective: screening of antibacterial activity. Brazilian Journal of Food Technology, 15, 11-17. http://dx.doi.org/10.1590/ S1981-67232012005000033.

49. Millezi, A. F., Baptista, N. N., Caixeta, D. S., Rossoni, D. F., Cardoso, M. G., \& Piccoli, R. H. (2014). Chemical characterization and antibacterial activity of essential oils from medicinal and condiment plants against Staphylococcus aureus and Escherichia coli. Revista Brasileira de Plantas Medicinais, 16(1), 18-24. http://dx.doi.org/10.1590/S1516-05722014000100003.

50. Uzeli, D. H. (2013). Estudo sobre o gás ozônio formado no processo de irradiação industrial com Cobalto-60 e seu impacto no meio ambiente. São Paulo: IPEN. http://dx.doi. org/10.11606/D.85.2013.tde-28012014-091422.

Received: Jan. 23, 2017

Revised: July 04, 2017 Accepted: Jan. 23, 2018 